\title{
Effect of Inorganic Nutrients and Bio-inoculants on Yield, Nutrient Uptake and Quality of Blackgram (Vigna mungo L.)
}

\author{
Shubham Srivastav*, R.N. Dixit, Pushpendra Kumar and Akansha Singh \\ C.S. Azad University of Agriculture and Technology, \\ Kanpur-208002, U.P., India \\ *Corresponding author
}

\section{A B S T R A C T}

\section{Keywords \\ Inorganic nutrients Bio-inoculants yield, Nutrient uptake}

Article Info

Accepted:

08 June 2018

Available Online:

10 July 2018
A field experiment was conducted in micro plots of the size $1.44 \mathrm{~m}^{2}$ at experimental area of Department of Soil Science and Agricultural Chemistry in Chandra Shekhar Azad University of Agriculture and Technology, Kanpur during Kharif, 2016 to study the combined effect of biological nitrogen fixing bacteria with phosphate solubilizing bacteria as affected by different levels of nutrients on Blackgram (Vigna mungo L.). Four levels of nutrients i.e. control, $75 \%$ SR, $100 \%$ SR and $125 \%$ SR of NPK were integrated with different bio-fertilizer viz. Rhizobium, PSB, Rhizobium+ PSB and with uninoculated. The experimental results revealed that the grain yield significantly increased by single inoculation with Rhizobium and PSB up to the level of $12.11 \mathrm{qha}^{-1}$ and $13.40 \mathrm{qha}^{-1}$. The dual inoculation (Rhizobium+ PSB) was also signification increased the grain yield up to level of $14.15 \mathrm{qha}^{-1}$ in comparison to $10.63 \mathrm{qha}^{-1}$ in uninoculants. The maximum grain yield was obtained $17.33 \%$ SR of NPK, The lowest yield was recorded $6.00 \mathrm{qha}^{-1}$ with respective control. Seed inoculation with Rhizobium, PSB and dual inoculation with (Rhizobium + PSB) was found effective to increase number of nodules, Plant height, branches plant ${ }^{-1}$ and protein percent content. From the investigation results showed that dual inoculation and (Rhizobium+ PSB) was significantly superior in comparison to single inoculation and uninoculation respectively.

\section{Introduction}

The pulses occupy a unique position in world agriculture by virtue of their high protein content and their capacity to fix up atmospheric nitrogen. The present India's population is 1210 million and is expected to go up to 1279 million in 2020 and 1374 million in 2030. At the present the rate of consumption, demand for pulses would increase annually by 3.3 per cent. It has been estimated that the requirement of pulses is likely to be around 19 million tonnes in 2021followed by 24-26 million tonnes in 2030. This will require about 75 percent increase in the production by the year 2030 . Thus, the present productivity of 0.6 tonnes per hectare will have to be raised to 0.99 tonnes per hectare in with 35 percent of the world's area and 27 percent of the production. India is the largest pulses producing country. These crops occupy nearly 252.59 lakh 
hectare of land with the production around 16.47 million tonnes. The average productivity of pulses in India is $6.52 \mathrm{q} / \mathrm{ha}$ in 2015-2016.

Pulses crop play an important role in sustaining intensive agriculture by improving physical, chemical and biological properties of soil and are consider excellent crops for diversification of cereals- based cropping systems. Total pulses production was recorded $16.47 \mathrm{mt}$. in 2015-2016 (Source: Directorate of Economics and statistics) in India. The risk factors in pulses can be minimized through better management of fertilizer and biofertilizer, disease, pests, water and use of improved varieties. The key to successful pulse cultivation lies in fine turning of all required inputs. Pulse crops have certain unique features which together make them indispensable if not difficult to replace. Firstly, pulse crop play an important role in agricultural economy of India by virtue of their ability to fix atmospheric nitrogen in symbiotic association with Rhizobium.

They are more drought tolerant comparison to any other cereal due to their deep root penetration system. The pulse proteins are rich in lysine and poor in sulphur containing amino (cysteine, methionine etc.) acids. Black gram grain contains about 24 per cent protein, 60 percent carbohydrates, and 1.3 percent fat and is the richest among the various pulses in phosphoric acid.

The bio-fertilizer have been recognized as the cheapest fertilizer input in agriculture in the developing countries like India as a source of supplement to the application of nitrogen and phosphorus fertilizers for better crop production. It is known that about 4000 million tonnes of nitrogen is present in atmosphere, which comes about 77 thousand tonnes over an area of one hectare land. It is very essential to utilizable by crop through biological fixation by certain useful micro organism. Among these micro-organism, Rhizobium plays an important role by supplementing nitrogen in legume crops.

Rhizobium is widely distributed in soils of tropics and has the ability to fix atmospheric nitrogen in symbiotic association. The amount of nitrogen fixed varies with strain to strain of Rhizobium.

The increase in legume grain yield due to Rhizobium inoculation has been responded well ranging from 10 to 35 percent among different pulses crops. Phosphate solubilising micro-organism is found in all soil but their number varies with different $\mathrm{P}$ source. Multilocation trial had indicated that $10-40$ percent Bengal gram by 10-30 percent and Potato by 30-50 percent (Gaur, 1991).

The biological nitrogen fixation has been estimated to contribute more than 175 million tonnes of nitrogen out of which legume $\mathrm{N}_{2}$ fixation accounts for all most 40\% (Burns and Hardy, 1975). Phosphate solubilising micro organism are found in all soil but their number vary with soil climate as well as history (Gupta et al., 1986).

\section{Materials and Methods}

The present experiment entitled "Effect of inorganic nutrients and bio-inoculant on yield, nutrient uptake and quality of Blackgram (Vigna mungo L.)" was conducted at Pot House experimental site, Department of Soil Science and Agricultural Chemistry, Chandra Shekhar Azad University of Agriculture and Technology, Kanpur under the Central Plain Zone. The experiment was carried out during Kharif season in the year of 2016. The details of materials used and methods adopted during the course of investigation are enumerated below. 


\section{Details of experimental material}

\section{Experimental site}

Geographically, the experimental site is located in Kanpur district in alluvial track of Indo Genetic Plains in Central Uttar Pradesh. Kanpur situated in $25.26-26.58^{\circ}$ North latitude and $79.3-80.37^{\circ}$ East longitude at an elevation of 125.9 meters above mean sea level.

\section{Experimental soil}

The soils of experimental field were sandy loam and deficient in organic carbon, nitrogen, phosphorus and medium in potash. Various samples were drawn from each micro plots up to a depth of 0 to $20 \mathrm{~cm}$. These samples were mixed thoroughly and a composite sample was made. Soils were analyzed before and after the crop for $\mathrm{N}, \mathrm{P}$ and $\mathrm{K}$ to see the dynamics of these nutrients in soil and plant. This sample was used for mechanical and chemical analysis by standard analytical procedures given by scientist from time to time (Table 3 ).

\section{Experimental details: Experimental design and treatments}

The experiment was conducted with four levels of Nutrient (NPK) and four source of bio-inoculants viz., Uninoculant, PSB, Rhizobium and PSB+Rhizobium consisting 16 treatment combinations with 3 replication as indicated in below table 1 .

\section{Cultural operation}

\section{Land preparation}

To obtain fine seed bed, ploughing was done upto $30 \mathrm{~cm}$ depth using tractor -drawn plough followed by harrowing for clod crushing and removing the stubbles of previous crop and weeds. Stubbles were picked to clean the field.

\section{Seeds and sowing}

The certified seeds of black gram, $\mathrm{T}_{9}$ were sown@ $15 \mathrm{~kg} / \mathrm{ha}$. The sowing was undertaken after receipt of sufficient rains by drilling method keeping $30 \mathrm{~cm}$ distance between two rows while plant to plant distance maintained was $10 \mathrm{~cm}$.

\section{Thinning and gap filling}

After one week of sowing, gaps were filled wherever necessary in the black gram crop.

\section{Fertilizer application}

The fertilizers were applied as per treatments. The recommended dose of fertilizer $(25 \mathrm{~kg} \mathrm{~N}$, $50 \mathrm{~kg} \mathrm{P}_{2} \mathrm{O}_{5}$ and $50 \mathrm{~kg} \mathrm{~K}_{2} \mathrm{O}$ ) was applied through urea $(46 \% \mathrm{~N})$, Diammonium Phosphate $\left(18 \% \mathrm{~N}, 46 \% \mathrm{P}_{2} \mathrm{O}_{5}\right)$ and Muriate of potash $\left(60 \% \mathrm{~K}_{2} \mathrm{O}\right)$.

\section{Biofertilizer application}

Rhizobium culture was obtained from department of microbiology of this university. Phosphate solublizing bacteria (PSB) was obtained from Division of microbiology, IARI New Delhi.

Seed treatment with biofertilizers viz., Rhizobium and phosphate solubilising bacteria were applied as per treatment by inoculating black gram seeds with biofertilizers culture @ $25 \mathrm{~g} / \mathrm{kg}$ of seed by slurry method.

The seed inoculation was done as per the treatment.

\section{Intercultural operations}

The weeds were controlled by giving two hand weeding and one hoeing. The crops were kept free from weeds up to 30 days after sowing. 


\section{Harvesting and threshing}

Harvesting was done manually when the crop showed physiological maturity and the grains were completely matured. The harvesting was done by picking of pods. Border rows were harvested and kept separately and then crop from each net plot area was harvested separately. The harvested produce from each net plot was collected in different bags as per treatment. Observation plants were harvested separately and were taken to the laboratory for postharvest studies. After sun drying the produce from each net plot was threshed manually and clean seeds were obtained by winnowing.

\section{Biometric observation}

Five plants were randomly selected from each net plot treatment-wise in all replications. The plants were labeled and various biometric observations were recorded on these plants periodically after 15 days of interval till maturity of the crop.

\section{Plant height}

Height of the plant was measured in $\mathrm{cm}$ from the base of the plant to the tip of the main stem shoot. The observation was recorded periodically at an interval of 30 days from sowing till harvest of the crop.

\section{Number of branches/plant}

The numbers of branches/plant were recorded from the five selected plants and mean number of branches/plant was worked out.

\section{Number of root nodules}

Plant took out carefully with the help of a fork. The roots were then washed by water and the functional root nodules were counted. The mean number of nodules/plant was reported.

\section{Test weight}

Thousand grains were counted from representative samples from each net plot and weighed separately. This thousand grains weight was worked out as test weight.

\section{Grain yield per hectare}

The plants harvested from net plot were threshed, cleaned and grain weight/plot was recorded separately. The grain yield was then converted into hectare yield $\left(\mathrm{kgha}^{-1}\right)$.

\section{Straw yield per hectare}

Straw yield was obtained by deducting the weight of grains from the biological yield of respective net plot and converted into per hectare yield $\left(\mathrm{kgha}^{-1}\right)$.

\section{Results and Discussion}

An experiment entitled "Effect of inorganic nutrients and bio-inoculant on yield, nutrient uptake and quality of Blackgram (Vigna mungo L.)" was conducted during the kharif season of 2016 at Pot House experimental site, Department of Soil Science and Agricultural Chemistry, Chandra Shekhar Azad University of Agriculture and Technology, Kanpur under the Central Plain Zone. During the course of field experimentation, the observations recorded on different growth characters, yield attributes and yield of black gram as influenced by different treatments are presented in this chapter under appropriate heads.

\section{Plant height (cm)}

The plant height of Blackgram was significantly influenced due to seed inoculation of biofertilizer at all the growth stages of crop comparison to uninoculated ones. The maximum plant height of $18.50 \mathrm{~cm}$ and $31.50 \mathrm{~cm}$ was observed at 30 and 60 DAS respectively by the application of 
$125 \%$ SR+Rhizobium+PSB. The data of plant height are presented in table 3 .

Nutrients application also significantly increased plant height showing the values of $13.00 \mathrm{~cm}, 14.10 \mathrm{~cm}$ and $15.60 \mathrm{~cm}$ in $30 \mathrm{DAS}$ and $24.60 \mathrm{~cm}, 26.50 \mathrm{~cm}$ and $27.75 \mathrm{~cm}$ as 60DAS after applied $75 \%$ SR, $100 \%$ SR and $125 \mathrm{SR} \%$ of NPK as compared to $11.85 \mathrm{~cm}$ in 30 days and $21.90 \mathrm{~cm}$ as 60 days in control. Increase in plant height might be due to the nitrogen application increased growth of the plant, since nitrogen as a major component of protoplasm helps in photosynthesis and enhances metabolic rate, cell division and cell elongation which thereby, allow the plant grow faster and phosphorus enhances the root elongation, leaf expansion and helps in cell elongation.

The interaction effects were non-significant at all the stages of crop growth. The results are in agreement with the finding of Balachandran and Nagrajan (2002) and Khatkar et al., (2007).

\section{Number of branches after 60 DAS}

The data presented in Table 3 indicated that microbial inoculation and nutrients have significant effect on number of branches. The inoculation of Rhizobium, PSB and dual inoculation (Rhizobium+PSB) were counted as 5.73, 5.25 and 6.13 as comparison to uninoculant counted 4.81. The combined seed inoculation with Rhizobium+PSB improved N and $\mathrm{P}$ status of soil and ultimately increased $\mathrm{N}$ and $\mathrm{P}$ uptake which enhanced growth attributes The nutrients application of $75 \%$ SR, $100 \%$ SR and $175 \%$ SR of NPK enhanced the branches per plant as comparison to control. Finding are in conformity with Gangwar and Dubey (2012). The interaction effects were found non-significant.

\section{Table.1 Treatment}

\section{A. Nutrients levels (NPK)}
(1) Control: No
(2) $75 \%$ SR : N1
(3) $100 \% \mathrm{SR}$ : N2
(4) $125 \% \mathrm{SR}: \mathbf{N 3}$

\section{B. Bio-inoculant (B)}
(1) No inoculation
: B0
(2) Rhizobium : B1
(3) PSB : B2
(4) Rhizobium + PSB : B3 
Table.2 Description of experimental field

S.No.

1. Statistical Design

(Factorial)

2. No. of total treatment

3. No. of replication

4. Total No. of plots

5. Size of one plot

6. Field border

7. Crop

8. Variety of the crop

9. Sowing date

10. Harvesting time

11. Source of phosphorus \& nitrogen

12. Source of potash
Particulars

Randomized Block Design

16

03

48

$1.20 \times 1.20$ meter

1 meter

Blackgram

T-9

03 Sept. 2016

28 Nov. 2016

DAP

MOP

Table.3

\begin{tabular}{|c|c|c|c|c|c|c|c|c|}
\hline \multirow{2}{*}{$\begin{array}{l}\text { Treatments } \\
\text { Bioinoculant }\end{array}$} & \multicolumn{2}{|c|}{$\begin{array}{l}\text { Plant height } \\
\text { (cm.) }\end{array}$} & \multirow{2}{*}{$\begin{array}{c}\begin{array}{c}\text { No. of } \\
\text { Branches }\end{array} \\
60 \text { DAS }\end{array}$} & \multicolumn{3}{|c|}{ Number of nodules plant $^{-1}$} & \multirow{2}{*}{$\begin{array}{c}\begin{array}{c}\text { Seed yield } \\
\left(\text { qha }^{-1}\right)\end{array} \\
-\end{array}$} & \multirow{2}{*}{$\begin{array}{c}\text { Stover yield } \\
\left.\text { (qha }^{-1}\right) \\
-\end{array}$} \\
\hline & $\begin{array}{c}30 \\
\text { DAS }\end{array}$ & $\begin{array}{c}60 \\
\text { DAS }\end{array}$ & & 30DAS & $\begin{array}{c}45 \\
\text { DAS }\end{array}$ & 60 DAS & & \\
\hline $\mathbf{B}_{0}$ & 13.17 & 24.71 & 4.81 & 8.27 & 12.86 & 8.62 & 10.63 & 13.54 \\
\hline $\mathbf{B}_{1}$ & 15.79 & 27.04 & 5.75 & 11.00 & 17.25 & 12.00 & 13.40 & 17.65 \\
\hline $\mathbf{B}_{2}$ & 15.40 & 26.05 & 5.25 & 10.04 & 15.62 & 10.61 & 12.51 & 16.10 \\
\hline $\mathbf{B}_{3}$ & 16.82 & 28.05 & 6.13 & 12.62 & 19.35 & 13.33 & 14.15 & 19.30 \\
\hline SE (d) & 0.247 & 0.438 & 0.170 & 0.175 & 0.300 & 0.238 & 0.239 & 0.350 \\
\hline CD at $5 \%$ & 0.503 & 0.839 & 0.346 & 0.356 & 0.611 & 0.485 & 0.487 & 0.713 \\
\hline Nitrogen Level & - & - & - & - & - & - & - & - \\
\hline $\mathbf{N}_{0}$ & 11.85 & 21.90 & 3.08 & 7.05 & 9.80 & 5.75 & 7.37 & 11.45 \\
\hline $\mathbf{N}_{1}$ & 15.50 & 26.65 & 5.37 & 10.62 & 17.03 & 11.43 & 12.82 & 16.88 \\
\hline $\mathbf{N}_{2}$ & 16.66 & 28.75 & 5.89 & 12.00 & 18.50 & 13.11 & 14.58 & 18.43 \\
\hline $\mathbf{N}_{3}$ & 17.15 & 29.81 & 6.88 & 13.12 & 19.75 & 14.25 & 15.91 & 19.83 \\
\hline SE (d) & 0.247 & 0.438 & 0.170 & 0.175 & 0.300 & 0.238 & 0.239 & 0.350 \\
\hline CD at $5 \%$ & 0.503 & 0.839 & 0.346 & 0.356 & 0.611 & 0.485 & 0.487 & 0.713 \\
\hline
\end{tabular}




\section{Number of nodules}

Nodules are serving as the seat of nitrogen fixation. The significant differences due to seed inoculation with biofertilizer was noticed at 30 , 45 and 60 DAS and dual inoculation (Rhizobium + PSB) of seed produced a higher no. of nodules plant ${ }^{-1}$ over the rest of treatments at all the stages. The number of nodules observed at all the three stages is given in the table 3 . The maximum number of nodules to the extent of 19.35 per plant was noticed in dual inoculation of Rhizobium+PSB followed by Rhizobium 17.25, PSB 15.62 alone, respectively against the control value of 12.86 per plant. Similar trend was found at 45 and 60 DAS of crop growth. The number of nodules was slightly decreased at 60 DAS. The increased number of nodules might be due to increased population of Rhizobial cells in the rhizosphere in the inoculated treatment. Similar observation were also reported Nagrajan and Balachander (2001), Singh and Sharma (2001).

\section{Grain and Stover yield}

The grain and stover yields were also significantly increased by Rhizobium, PSB inoculation. Rhizobium, PSB and dual inoculation showed the grain yield of 12.51, 13.40 and $14.15 \mathrm{qha}^{-1}$ as compared to $10.63 \mathrm{qha}$ 1 without inoculation. Similarly, stover yield increased to $16.10,17.65$ and 21.11 with Rhizobium, PSB and dual inoculation as compared to $13.54 \mathrm{qha}^{-1}$ without inoculation. These results are in agreement with the findings of Khan et al., (2010), Singh et al., (2010), Dhyani et al., (2011), and Zaman et al., (2013)

The yield increment in legumes due to PSB inoculation has been reported by Kumar et al., (2008) and Lal et al., (2012). There was further increase in grain and stover yield when both the inoculants were combined with each other. The higher increase in the yield of crop due to dual inoculation as compared to single ones has also been reported by Singh et al., (2006), Sharma and Khanna (2011), Prasad et al., (2012) and Ali et al., (2013).
The nutrients application significantly increased grain and stover yield of Blackgram. The treatment without nutrient showed the low grain yield over one with nutrients. Similar trends are found in case of stover yield. The optimum dose of nutrients as obtained in present study corroborated with the finding of Patel et al., (2005) and Waghmare et al., (2012)

The interaction of bio-inoculants and nutrient application regarding yield of crop was found non-significant statistically, but apparently, it was clear that the response of bio-inoculation was found visible at each level of nutrients. The maximum economic yield of crop was obtained in the treatment combination of Rhizobium+PSB and $125 \%$ SR of NPK.

From the present studies, it is concluded that the different microbial inoculants like Rhizobium, PSB and mixed inoculants increase the value of growth, characters, grain and stover yield of Blackgram. The treatment combination Rhizobium+PSB+125\%SR of NPK level proved beneficial for boosting the grain yield (17.33 $\left.\mathrm{qha}^{-1}\right)$ and thus it could be recommended to farmers for profitable production under central plain zone of Uttar Pradesh. The results are based on one year experiment hence requires validation through further experiments to formulate recommendation.

\section{References}

Ali, M., Ganeshamurty, A.N. and Srinivasarao, C. 2013. Role of plant nutrient management in pluse production. Fertizer News; 47(11):83-90.

Balachandran, D and P. Nagragan, 2002. Dual inoculation of Rhizobium and Phosphobacteria with phosphorus on Blackgram cv. Vamban 1. Madras Agric.J. 89(10-12):691-693.

Burn, R. C. and Hardy, RWF.(1975). Nitrogen fixation bacteria and higher plants, P, 189, Springer Verlage New Yorke.

Dhyani, B. P.; Yogesh Kumar; Shahi, U. P.; Ashok Kumar; Singh, R. R. and Singh, S. P. 2011. Effect of nitrogen, phosphorus, 
vermicompost and bio-fertilizers on growth and yield of urdbean Pantnagar Journal of Research; 9, 1, pp 72-74.

Gangwar, S. and Dubey, M. 2012. Effect on N and $\mathrm{P}$ uptake by chickpea (Cicerarietinum $L$.) as influenced by micronutrients and biofertilizers. Legume Research; 35(2):164-168.

Gaur, A.C. and Gaind, S 1991.Thermo-tolerant phosphate solubilizing micro-organisms and their interactions with mungbean. Plant and Soil, 133(1): 141-149.

Gupta, R. D., Bhradwaj, K. K. R., Marwah, B. C. and Tripathi, B. R. (1986).Occurrence of phosphate dissolving bacteria in sum soil of North West Himalayas under varying bio-sequences and climosequence, J. Ind. Soc. Soil. Sci.34: 498-504.

Khan, J. A., Banday, A. A. and Hassan, Z. 2010.Effect of bio-fertilizers (PSB, Azatobactor and their combination) on plant survival of Phaseolus aureusRoxb. Variety radiatus (mung/green gram).Environment and Ecology; 28(4):2326-2328.

Khatkar, R., T. Abraham and S.A. Joseph. 2007. Effect of biofertilizers and sulphur levels on growth and yield of Blackgram. Legume Res. 30(3):233-234.

Kumar,G., Srivastava, G.P. and Kumar R. 2008. Rooting pattern of blackgram as influenced by levels of phosphorus, sulphur and PSB in blackgram-toria cropping system. Journal of Research, Bisra Agriculture University;20(1):19-24

Nagaranjan, P. and Bala Chandar, D. 2001.Influence of Rhizobium and organic amendments on nodulation and grain yield of blackgram and greengram in acid soil. Madras AgriculturalJournal,88: 703705.

Patel, P. S., Ram, R. B., Jayprakash and Meena,
M. L. 2005. Effect of biofertilzers on growth and yield attributes of pea (Pisums ativum L.).Trends in Biosciences; 6(2):174-176

Prasad, M. and Yadav, D. 2012.Effect of different nitrogen sources and phosphate solubilizing bacteria on growth and yield of grain cowpea [Vigna unguiculata (L.)Walp.]. Crop Research (Hisar); 44(1/2):59-62.

Sharma, P. and Khanna, V. 2011. In vitro sensitivity of Rhizobium and phosphate solubilising bacteria to herbicides. Indian Journal of Microbiology; 51(2):230-233.

Singh, A.K; et. al. 2010.response of Rhizobium and different levels of molybdenum on growth nodulation and yield of blackgram (Vigna mungo L.), Environment and Ecology;28: 3A, 1728-1730.

Singh, D.D. and Sharma, A. 2001.Response of Blackgram (Phaseolus mungo L.) to phosphorus fertilization and Rhizobium inoculation in the soil. Annals of Agricultural Research; 22(1): 151-153.

Singh, S., Malik, R. K., Singh, R., Yadav, A. and Punia, S. S. 2006. Influence of irrigation, sulfur and seed inoculation on productivity, water use and crop coefficient of late-sown chickpea (Cicer arietinum). Environment and Ecology; 24(3): 576-581.

Waghmare, Y. M., Kalegore, N. K., Gokhale, D. N. and Chavan, D. A. 2012. Effect of integrated nutrient management on yield attributes, yield and quality of soybean (Glycine max (L.) Merill). Journal of Soils and Crops;22(2):321-326

Zaman, A., Sarkar, A. and Patra, B. C. 2009. Yield of summer soybean as influenced by phosphorus, VAM and PSB under different irrigation regimes. Indian Agriculturist; 53(3/4):125-127.

\section{How to cite this article:}

Shubham Srivastav, R.N. Dixit, Pushpendra Kumar and Akansha Singh. 2018. Effect of Inorganic Nutrients and Bio-inoculants on Yield, Nutrient Uptake and Quality of Blackgram (Vigna mungo L.). Int.J.Curr.Microbiol.App.Sci. 7(07): 882-889. doi: https://doi.org/10.20546/ijcmas.2018.707.107 